\title{
トピックス
}

\section{II. 診断と治療の進歩}

\section{3. 医療・介護関連肺炎 (NHCAP) の概念 亡診療}

\section{関雅文 朝野 和典}

要旨

医療・介護関連肺炎 (NHCAP) は日本独自の肺炎の概念である. 2011 年に発刊されたガイドラインでは, 耐性菌に配慮しつつも，誤嚥性肺炎を中心とした高齢者肺炎に特に焦点を当て，治療における倫理的配慮 も盛り込まれている. 高用量ペニシリン系薬を中心とした抗菌薬治療の一方, 今後の肺炎診療において, ワクチンに代表される予防や感染制御の考え方が, 特に重要であることが示唆されている.

〔日内会誌 $102 ： 2882 ２ 887,2013$ ]

肺炎ガイドライン, 誤嚥性肺炎, インフルエンザ, 耐性菌

\section{NHCAP とは?}

医療 - 介護関連肺炎 (Nursing and healthcareassociated pneumonia : NHCAP) とは, 2005 年に米国胸部疾患学会 (American Thoracic Society : ATS) と米国感染症学会 (Infectious Diseases Society of America：IDSA) が共同で発表 した院内肺炎（Hospital acquired pneumonia： HAP) ガイドラインにおいて, HCAP (Healthcare associated pneumonia：医療ヶア関連肺炎) として, 公式に初めて紹介された疾患概念であ る1,2).わが国では, 医療・介護関連肺炎：NHCAP という名称で 2011 年に提案され, わが国の現状 に則した形に修正されて発表されだ3.

国際的には, HCAPという名称が一般的であり,
その概念は, 当初, HAPの中でも, 特に耐性菌 のリスクが高い一連の肺炎群の一つとして挙げ られていた. しかし, そのオリジナルの定義を 見ると, 一見して, HCAPの要件を満たす肺炎患 者は, 純粋なHAPではなく, 市中肺炎 (Community-acquired pneumonia : CAP) とし て診療されることが多い可能性が高く, 従来の CAPとHAPの 2 分法では当てはまらない, その 中間に位置する肺炎群と考えるのが妥当とされ る1) (図 1).

さらに, 米国を中心とする多くのHCAPに関す る報告では, その原因菌の耐性度や予後（死亡 率)を見た場合, 実際にはHCAPのそれらは, 明 らかにCAPよりもHAPに近いことが明らかとな り,わが国からのその後の報告もほぼ同様であ る

\section{大阪大学医学部附属病院 感染制御部}

Diagnosis, Treatment and Prevention of Infectious Diseases. Topics : II. Progress in Diagnosis and Treatments of Infectious Diseases ; 3. Concept of nursing and healthcare-associated pneumonia (NHCAP) and its management.

Masafumi Seki and Kazunori Tomono : Division of Infection Control and Prevention, Osaka University Hospital, Japan. 


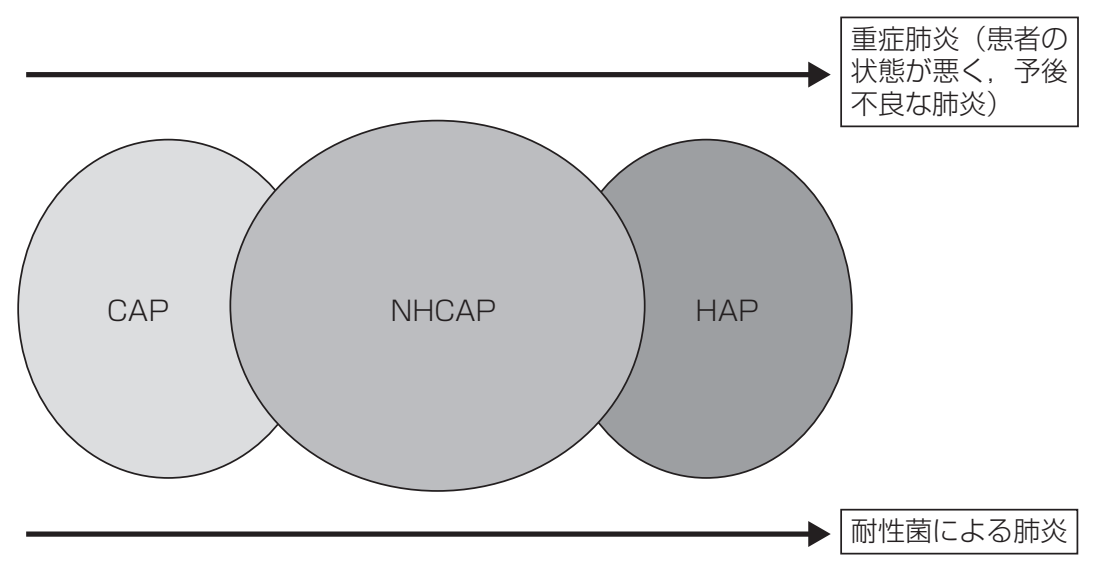

図 1. 医療・介護関連肺炎 (NHCAP) と市中肺炎 $(C A P)$ ・院内肺炎 (HAP) の位置づけの実際

なったHCAP患者でも, 一般的なCAP症例に比 べると, 高齢で合併症が多く, また, 原因菌も CAPによく見られる肺炎球菌やインフルエンザ 菌ではなく，MRSAや緑膿菌に代表される耐性 化の可能性が強いグラム陰性菌であることも多 いということである.

但し, その一方で, わが国の比較的健康な高齢 者が入所している施設からは, HAPよりもむし ろCAPに近いHCAPの状況も報告されている ${ }^{6}$.

したがって, HCAPはやはりCAPとHAPの中 間であり,その施設や地域の状況によって, CAP 寄りもしくはHAP寄りに対応していくことが重 要と言える (図 1).

\section{2. わが国のHCAP $=\mathrm{NHCAP}$}

前述のように, わが国におけるHCAPの報告か らも, HCAPの対象が比較的不均一で, 地域や施 設の性格に大きく反映されることがわかる.

また，わが国では，「病院」の定義が米国とは 大きく異なり，米国において「ナーシングホー ム」とされるような長期療養型の病床やいわゆ る「老人病院」が多く存在し, 米国でHCAPとさ れてきた肺炎の多くが, わが国ではHAPとして
扱われてきた点も大きい。この病院の定義が乘 離している点は 2008 年の院内肺炎ガイドライン 作成時にも大きな問題として挙げられていた7).

また，CAPからHCAPを俯瞰してみても，米 国での定義であればHCAPに相当するはずの, 自 宅で寝たきりの患者が誤嚥性肺炎を起こした場 合や，普段から透析を受けるなどして耐性菌の リスクファクターを持っている患者が肺炎を発 症し，近くの中核病院に搬送された場合，これ らの患者はHCAPではなく, CAPとして計上さ れてきたとも言える.

しかも，わが国には，欧米には存在しない介 護保険制度, それに基づいたいわゆる「老健」や 「特養」,「介護度」などの独自の施設システムも 存在するため, その点でも, 米国の定義をその ままの言葉で導入する際には大きな注意が必要 とわかった.

このような考えを基に, 2011 年に日本呼吸器 学会からHCAPに関する診療指針が「NHCAP」 ガイドラインとして提案された ${ }^{3)}$ (図 2). その定 義では, 特に（3）の項目が欧米のものと比べて 新しく，欧米の定義ではCAPとされてしまう, 自宅で介護保険下に診療を受けている患者も拾 い上げられるようになっている。ももちろん，従 
(1)長期療養型病床群もしくは介護施設に 入所している.

(2)90日以内に病院を退院した.

(3)介護を必要亡する高齢者, 身障者.

(4)通院にて継続的に血管内治療（透析, 抗菌薬, 化学療法, 免疫抑制薬等に よる治療)を受けている.

介護の基準

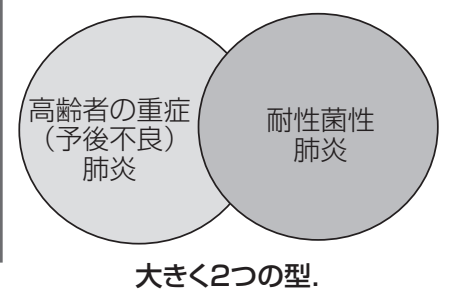

PS3 : 限られた自分の身の回りのことしかできない.

日中の 50\% 以上をべッドか椅子で過ごす，

以上を目安とする.

(1)には精神病床も含む.

図 2. 医療・介護関連肺炎 (NHCAP) の定義

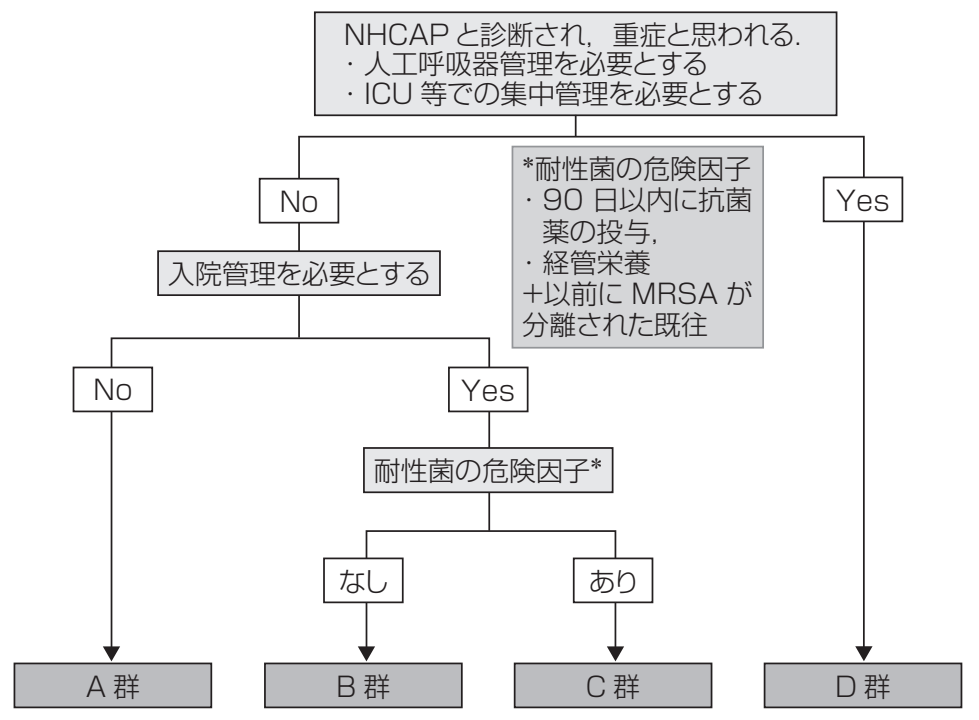

図 3.NHCAPガイドライン「治療区分」

来HAPとされてきた症例や,さらに高度医療の 結果生じた耐性菌性肺炎も, 欧米の定義同様に カバーされている.わが国における特有の医療 事情やシステムが反映された定義づけと言えよ う.

以上より，最初に述べたように，わが国にお けるこれらの肺炎群を示す言葉としてNHCAP： 医療・介護関連肺炎という言葉が適当との判断 がなされた訳である。「日本のHCAP=Nippon $\mathrm{HCAP}$ という意味も込められた, 独自性の強い
名称と言えよう.

\section{1）治療区分と抗菌薬選択}

NHCAP患者の具体的な分類とその治療に関し ては, ガイドライン中でアルゴリズムとして揭 載されている $(\text { 図 } 3)^{3}$.

肺炎患者の治療は通常, その重症度（個体側 の因子）と原因菌の耐性度（微生物側の因子）を 考慮して決定されるべきである.

NHCAPガイドライン 2011 では, 今までのADROPシステム $(\mathrm{CAP})^{8)}$ PI-ROADシステム 
$(\mathrm{HAP})^{7)}$ のような明確な重症度・予後予測因子を 見いだせなかったこともあり，「治療区分」とい う言葉で紹介されている。但し，一定の重症の 目安として人工呼吸管理とICU管理の必要性を提 案しており,これを満たす場合, D群=最重症と しての治療の適応となる.

その一方で, NHCAPガイドライン 2011 の中 では, 超高齢者に対する治療をどこまで行うか, 延命に関する倫理的側面も問われることを想定 し, あくまでも「主治医の判断」が大きな比重 を占めるべきであることを示した.この点も， 重症の目安が厳密なものとされなかった理由で あり, 今後大きな課題となるであろう. 多くの 一般病院で, 超高齢の入退院を繰り返している 症例への, 積極的な気管挿管や広域抗菌薬投与 の是非が問われていると言える.

また，耐性菌の因子に関しては，近々の「抗 菌薬投与の既往」と「経管栄養」が重要である ことが明らかとなった ${ }^{3,5)}$. 特に「経管栄養」は 行為そのものが直接, 耐性菌出現に関連するも のではないにせよ, そのような状態の患者では 多くが病態的にも問題があり，耐性菌を保有す る機会が多いためと推測された。高齢者肺炎診 療における経管栄養の是非が，この点でも論議 されるべき課題として改めて挙げられた.なお, この 2 項目に関しては, デー夕解析の上で陰性 的中率の方が高かったため,「ない場合はリスク なし」と判断するので, 注意が必要である.

\section{2）治療}

具体的な抗菌薬選択は（図 4)に挙げられる. 基本的な思想は今までの肺炎ガイドライン同様 であり，腎機能に配慮しつつも，高用量ペニシ リン系薬をエンピリックセラピーの中心とした. 耐性菌抑制のためにも，効率良く，比較的短期 間で治療を終了すべきである.

切り札とも言えるキノロン系薬やカルバペネ ム系薬はやはり温存すべきであるが, 高齢者が 多くを占めるNHCAP患者では, 肺に基礎疾患が
あり， $\beta$ ラクタム系薬では組織移行の面から治 療効果に若干の心配がある場合は, 逆にキノロ ン系薬を始めから積極的に使用すべきであるか もしれない。また，微生物学見地からはESBL などの耐性菌の関与が疑われる場合はカルバペ ネム系薬の使用がむしろ薦められると言えよう. その点で, NHCAPガイドライン 2011 は, キノ ロン系薬やカルバペネム系薬の使用に一定の基 準を示した踏み込んだ内容となった。

また, 今回の抗菌薬レジメンに関しては, 非 定型菌（特にクラミドフィラ）の合併と, 特に 重症肺炎での予後改善を目的とした特にマクロ ライド系薬の併用，誤嚥で特に重要な原因菌と なりうる嫌気性菌への配慮に積極的に言及した 点, まだ導入が実施されていないメトロニダゾー ル点滴薬にも言及した。これらの点でも世界標 準の抗菌化学療法がわが国でも現実的となって いると言えよう.

3）発症予防； ワクチンと胃ろうの位置づけ

NHCAPでは, 高齢者の予後不良肺炎の頻度が 高まる可能性は今までも言及した通りである. 抗菌薬の過剩な投与は, 副作用からかえって死 亡率を上げる可能性もあり，医療経済上も大き な問題となりうる，そのため，治療にもまして， 肺炎発症と重症化の「予防」がより重要となる.

NHCAPの主な発症機序として, 誤嚥性肺炎の 他, インフルエンザと関連する 2 次性細菌性肺 炎の重要性が提案された(表) ${ }^{3)}$. NHCAPガイド ライン 2011 の中でワクチンの重要性は言うまで もなく, 一連の肺炎ガイドラインの中ではじめ てワクチンの章が独立して記載されていること は特筆すべきである。これはわが国でも，高齢 者施設におけるインフルエンザワクチン，そし て肺炎球菌ワクチンの効果がはっきりと示され たことにもよる ${ }^{9)}$. 後, 行政を含めた, より積 極的なワクチンへの取り組みが一層期待される.

一方で, 誤嚥性肺炎の予防も, 院内肺炎の場 合にも増して，きわめて重要である ${ }^{3,7)}$. わが国 


\section{トピックス}

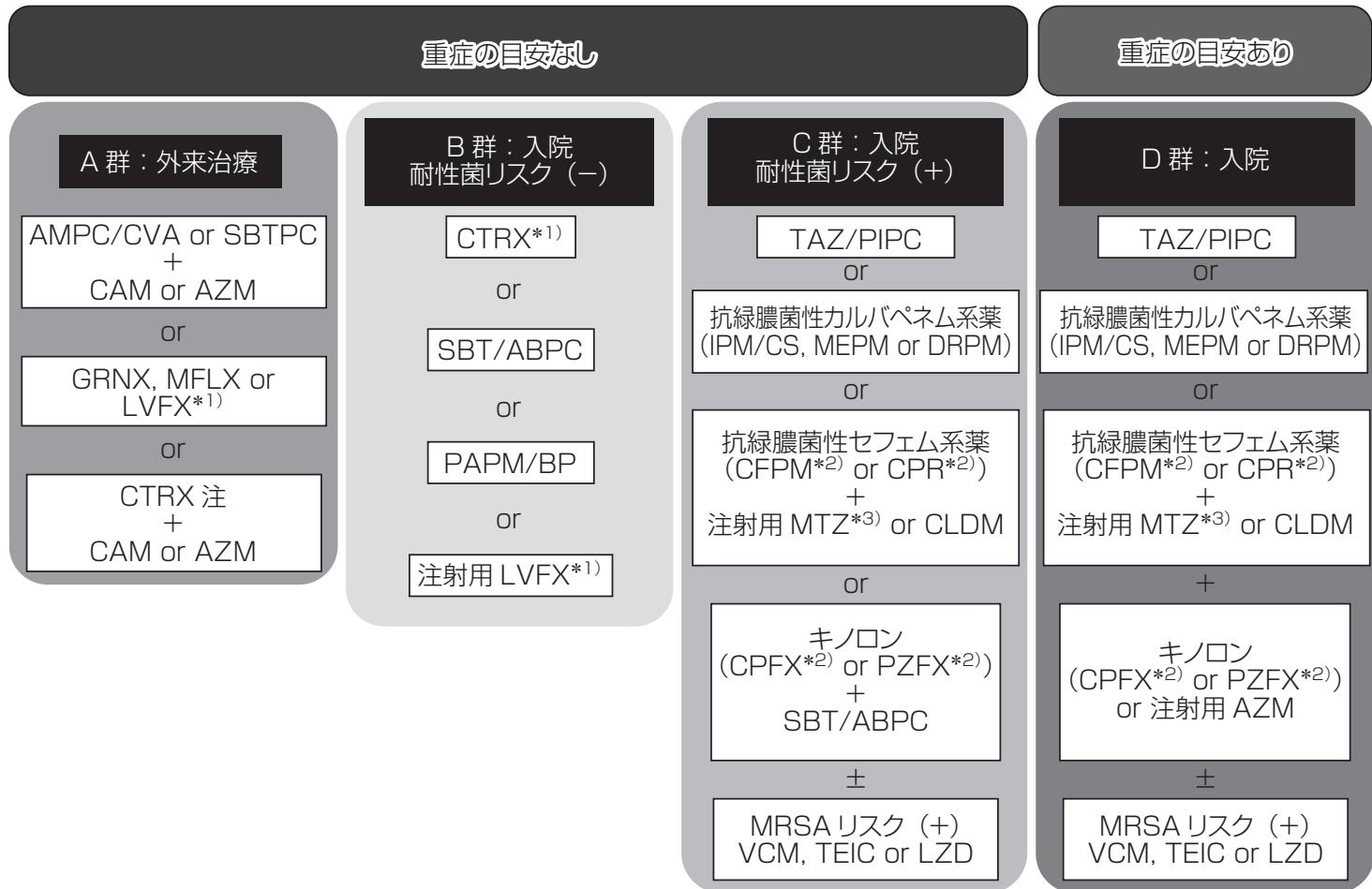

図 4. NHCAPガイドライン 2011 推奨抗菌薬

*1) 嫌気性菌に抗菌力が不十分なため, 誤嚥性肺炎疑いでは不適.

*2）嫌気性菌に抗菌力が不十分なため, 誤嚥性肺炎疑いでは嫌気性菌に抗菌活性を有する薬剤（MTZ, CLDM, SBT/ABPC等) と併用する.

*3) 2013 年 9 月現在, 本邦未承認.

\section{表. NHCAPの発症機序}

\section{(1)誤潇性肺炎}

(2)インフルエンザ後の二次性細菌性肺炎

（3)透析などの血管内治療による耐性菌性肺炎（MRSA 肺炎など）

(4)免疫抑制薬や抗癌剤による治療中に発症した日和見 感染症としての肺炎

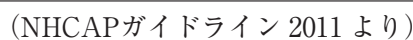

の高齢者診療において重要な位置を占めてきた 「胃ろう」に関しては，肺炎予防策としては必ず しも有用でないことが明記され，倫理的な側面 も含めて，今後さらに検討されるべき問題とし て取り上げた点は大きい。前述のように，経管 栄養が耐性菌のリスクとして挙げられた点も含
めて，これらの処置を見合わせ，呼吸ケアやリ ハビリなどの観点から，誤嚥予防を今後大きな 研究課題として，職種を超えて取り組んでいく 必要性も重要な課題として挙げられている。

おわりに

今後も多くの意見が寄せられると共に，エビ デンスが蓄積されて，さらに実際的な定義，そ して診療アルゴリズムが作られることが期待さ れる. 法律家や宗教研究家も入れた高齢者肺炎 に対する積極的な討議も必要となろう.

一方で，耐性菌性肺炎，特にMRSA肺炎など の診断，すなわち単なる保菌者に感染症として 
の, 過㮃な抗菌薬治療が行われている可能性も 改めて示唆されつつある ${ }^{3,7,10)}$.

今後は，これらの問題に明確な答えを出しつ つ, CAP, HAP, NHCAPを統合した, よりシン プルで実用的な肺炎ガイドラインの作成が次の ステップとして現実的となってきた.

超高齢社会がさらに進む中で, NHCAPの概念 と診療の重要性はますます高まっていると言え よう。

著者のCOI (conflicts of interest) 開示: 本論文発表内容に 関連して特に申告なし

\section{文献}

1) ATS/IDSA : Guideline for the Management of Adults with Hospital-acquired, Ventilator-associated, and Healthcare-associated Pneumonia. Am J Respir Crit Care Med 171 : 388-416, 2005.

2) Kollef MH, et al:Health Care-Associated Pneumonia (HCAP) : A Critical Appraisal to Improve Identification,
Management, and Outcomes - Proceedings of the HCAP Summit. Clinical Infectious Diseases 46 : S296-334, 2008.

3）日本呼吸器学会：NHCAPガイドライン. 2011.

4) Seki M, et al:Characteristics and disease severity of healthcare-associated pneumonia among patients in a hospital in Kitakyusyu, Japan. J Infect Chemother 17: 363-369, 2011.

5) Shindo $Y$, et al:Health-Care-Associated Pneumonia Among Hospitalized Patients in a Japanese Community Hospital. Chest 135 : 633-640, 2009.

6) Maruyama $\mathrm{T}$, et al: A prospective comparison of nursing home-acquired pneumonia with hospital-acquired pneumonia in non-intubated elderly. Respiratory Medicine 102 : 1287-1295, 2008.

7) 日本呼吸器学：院内肺炎ガイドライン. 2008.

8）日本呼吸器学市中肺炎ガイドライン。 2005/2007.

9) Maruyama $\mathrm{T}$, et al : Efficacy of 23-valent pneumococcal vaccine in preventing pneumonia and improving survival in nursing home residents:double blind, randomised and placebo controlled trial. BMJ $3: 1004,2010$.

10) Sakaguchi M, et al:Current problems in the diagnosis and treatment of hospital-acquired methicillin-resistant Staphylococcus aureus pneumonia. J Anesthesia 22: 125130, 2008. 